\title{
Stakeholder Relationships and Responsibilities: A New Perspective*
}

\author{
Chiara Civera**, R. Edward Freeman ${ }^{* * *}$
}

\begin{abstract}
The intensifying debate about stakeholder-oriented relational approaches replacing a pure economic-based perspective has contributed to new stakeholder thinking based on cooperative relationships and mutual and shared responsibilities.

In this paper, we provide a new configuration of stakeholder relationships and responsibilities by first discussing three main antecedents of such a differentiated perspective: (a) the failure of the separation thesis; $(b)$ the importance of stakeholder continuous engagement and joint value creation; and (c) the key role of creative imagination. Second, we use these antecedents to illustrate a multi-stakeholder value map that sheds light on the centrality of all stakeholders in a joint value creation emergent process. We posit that adopting such an approach might increase the value creation for all actors, whether directly or indirectly involved in specific multistakeholder alliances, and benefit the firm, the industry and the society from a larger perspective beyond one that is merely economic-based.
\end{abstract}

Keywords: Stakeholder theory; Stakeholder relationships; Responsibility; Multistakeholder value map; Joint value creation

\section{Antecedents for a New Stakeholder Thinking}

Academic contributions and applications of stakeholder theory have intensified over more than 30 years of academic research; this has resulted in new discussions and theoretical propositions of the theory applied to the business and management disciplines and other fields (Freeman et al., 2010). Fresh perspectives on stakeholder thinking have opened the traditional stakeholder management research to directions that can:

- develop a new narrative of stakeholder theory and shape a new story of business that relies on more consolidated and integrated stakeholder relationships and responsibilities (Freeman et al., forthcoming; Andriof et al., 2002);

- improve the understanding of stakeholder engagement (Greenwood, 2007) and expand the debate about the fairness of organization-stakeholder relations and the key role of trust (Greenwood \& Van Buren III, 2010);

\footnotetext{
* The Authors: Civera, C. §§ 1, 3, 4, Freeman, R.E. §§ 2, 6

**Assistant Professor of Strategic Marketing, University of Turin (chiara.civera@ unito.it)

**** Elis and Signe Olsson Professor of Business Administration, Darden School of Business, University of Virginia (freemane@ darden.virginia.edu)
}

Edited by: Niccolò Cusano University ISSN: 1593-0319

Civera, C. \& Freeman, R.E. (2019). Stakeholder Relationships and Responsibilities: A New Perspective, Symphonya. Emerging Issues in Management (symphonya.unicusano.it), 1, 40-58. 
- clarify the meanings of power and empowerment for more vulnerable categories of stakeholders that are increasingly participating in value creation processes (Civera et al., 2019; Freeman et al., 2018; Dawkins, 2014, 2015);

- shed light on the importance and effectiveness of multi- and intra-stakeholder relationships for strategic decisions (Fassin et al., 2017; Zeyen et al., 2014);

- develop a stakeholder theory of an individual stakeholder's contribution to joint value creation (Bridoux \& Stoelhorst, 2016); and

- emphasize the optimistic view of human beings and develop a stakeholderoriented relational approach that is based on kindness, honesty, and positive values (Harrison et al., 2010; Jones \& Felps, 2013).

Bearing John Elkington's (2018) words in mind, we must admit that very often management concepts are recalled by people who invented them, and at the same time, enlightened theories are adjusted by scholars in a way that best fits their research purposes as well as their thinking and backgrounds. As a result of this evolution, management theories might lose some of their original characteristics on their way to becoming the point of reference for popularity and understanding. In the specific case of stakeholder theory, the stress on what companies should or should not do with their stakeholders seems to have become the core of the argument. Another element of the argument is that companies should look at their stakeholders in a way that considers relationships, cooperation, individuality of stakeholders, and interdependency among all actors (Soundararajan et al., 2016; Salvioni and Astori, 2013; McVea \& Freeman, 2005) instead of looking only at roles and economic dependency of stakeholders in a firm-centric perspective. The mutuality of influence and impact within stakeholder relationships seems to have been, therefore, fully addressed and well understood by most scholarship, who applied what Freeman (1984) originally had in mind. Some studies, however, found stakeholder thinking to be a characterization based on roles, dependency, and prioritization, stressing the power and the perspective of the firm to assess and categorize stakeholders. Mitchell et al., (1997), for instance, postulated that stakeholders are dependent on the company, and their role is determined by their power, legitimacy and urgency of claims, to which the firm reacts and creates social and economic value, not necessarily simultaneously (Tashman \& Raelin, 2013). Similarly, the focus on transactions (i.e., economic or market pricing) among stakeholders, rather than on relationships, seems to still be valid in certain contexts. Even if utilizing the logic of market pricing to create value in joint and cooperative terms does not lead to higher social outcomes (Venkatamaran, 1997), Bridoux \& Stoelhorst (2016) explain that this logic still permeates stakeholders' minds and actions because stakeholders, most of the time, perceive self-interested behaviors by the firm.

In this sense, the links and overlaps between stakeholder theory and corporate responsibility (i.e., Corporate Social Responsibility [CSR])-even though not fully clarified or largely addressed by researchers (Freeman \& Dmytriyev, 2017)-become more obvious to prove that firms, as united individuals, are not necessarily acting in a self-interested way; the relationships between firms and stakeholders along their value chain might as well be included in the company's full range of responsibilities, beyond the social aspects (see also Brondoni, 2003 and Brondoni, 2014). These 
behaviors are identified with CSR definitions that go beyond mere social responsibility, such as Company Stakeholder Responsibility (Freeman \& Velamuri, 2006) or Integrated Company Responsibility (Civera, 2018; Mosca \& Civera, 2017). If we think about multi-stakeholder initiatives (MSIs)-private governance mechanisms involving a plurality of stakeholders for coping with the increasing number of social, environmental, and ethical global pressures (Mena \& Palazzo, 2012) — we look at the higher expression of integration between stakeholder theory and company stakeholder responsibility. MSIs, as a matter of fact, not only provide some norms for corporate behaviors but also are the result of both firms' and stakeholders' behaviors, which are "the product of purposeful decisions and negotiations of pioneer members with diverse interests" (Zeyen et al., 2016, p. 342). Clearly, this puts the responsibility of decisions and actions within MSIs on all stakeholders, including the firm, and implies a stronger cooperative strategic posture and jointly held interest among all groups involved (Strand \& Freeman, 2015), which become as central as the firm in the interest of value creation (Boiral \& HerasSaizarbitoria, 2017).

In this paper, we seek to reinforce the stakeholder theory relational approach based on a new story of business that both acknowledges the centrality of all stakeholders, the importance of purpose, values and ethics, and the complexity of human beings, and relies on honesty, kindness, and business integration in society and with stakeholders (Freeman et al., 2010; Harrison et al., 2010; Jones \& Felps, 2013). This view contrasts with a stakeholder theory transactional approach that uses a dichotomous narrative to explain company-stakeholder links and overlaps. First, we aim at substantiating the need to go beyond economic theory's focus on transactions (Bridoux \& Stoelhorst, 2016; Freeman et al., 2010) to emphasize stakeholder relationships and responsibilities utilizing a joint value creation focus and considering the perspectives of the industry and the society where stakeholders stand. We adopt such a perspective because the globalized environment, together with technological improvements, connects us all, and firms are linked together in a newly competitive/cooperative environment that impacts industries and stakeholders in the industry and the society simultaneously (Brondoni, 2014). We will develop an explicit conversation about the new thinking on stakeholder relationships and responsibilities around three main pillars of stakeholder theory and integrated company stakeholder responsibility in order to underline how carrying on such new thinking can lead to a new narrative for both business and stakeholders. The three pillars of discussion are the following: (a) contesting the separation thesis; (b) adopting the perspective of continuous engagement and joint value creation; and (c) reconfiguring multi-stakeholder relationships and responsibilities using creative imagination. Our second contribution is a multi-stakeholder value map that is intended to reframe stakeholder assessment in terms of relationships rather than competitive transactions across markets based on stakeholder roles, power, and legitimacy. We suggest that stakeholders need to frame their relationships in terms of joint value creation and communal interest (from Bridoux \& Stoelhorst, 2016) and propose that acting in the interest of the industry and the society might increase the 
value of multi-stakeholder initiatives (or alliances) and benefit the firm from a larger perspective than merely economics.

The remainder of this paper unfolds as follows: Sections 2, 3, and 4 contain the discussion around the three pillars of stakeholder theory and integrated company stakeholder responsibility that will function as antecedents to illustrate the multistakeholder value map under the lens of joint value creation in Section 5. In the last section, we will discuss our conclusive remarks and the emerging issues for future studies.

\section{Contesting the Separation Thesis}

In 1970, Friedman (University of Chicago) defined all intellectuals and businessmen who were arguing about the moral standing and the social conscience of businesses as:

"unwitting puppets of the intellectual forces that have been undermining the basis of a free society these past decades" (The New York Times Magazine, September 13, 1970).

His most-quoted idea was that the only responsibilities businesses have is to increase their profits, and to support his thesis, he conceptualized the firm as an "artificial person" with no other responsibilities—unlike "real" human beings-than paying back the owners and acting in the interest of the business itself.

In these past decades, many have been the interpretations of Friedman's view stressing on the natural and justified self-interest of managers within a capitalistic system. Scholars have been positioning Friedman as one of the main opponents to stakeholder theory. However, if we look deeply at what he supports, we might argue, as Freeman has already done in some of his works (Agle et al., 2008; Freeman et al., 2010), that Friedman's view can be "compatible with stakeholder theory - in fact we see Friedman as an early stakeholder theorist" (Freeman et al., 2010, p. 10). This is a strong statement that can be validated if we understand that for Friedman it is within capitalism that stakeholder interests are pursued and not within corporate social responsibilities. Supporting this argument, it is Freeman himself who wanted to end the so-called "Friedman-Freeman debate" (Agle et al., 2008, p. 162) and open a broader understanding of Friedman's words under the lens of stakeholder theory. In Freeman's view, the two ideas are just about two different things. On the one hand, Friedman focuses on markets and how they work and believes that maximizing profits makes business successful. In Capitalism and Freedom (1962), he claims that the purpose of a business is to "engage in activities designed to increase its profits so long as it stays within the rules of the game, which is to say, engages in open and free competition, without deception or fraud" (Friedman, 1962, p. 133). On the other hand, stakeholder theory is "not a theory of the firm. Rather it is a very simple idea about how people create value for each other. It's a theory about what good management is" (Agle et al., 2008, p. 166). Talking about profit and purpose leads to two different territories that are, yet, interlinked, in today's landscape more than in 
the past. Businesses have, in fact, multiple purposes and creating value for stakeholders is one of the ways to create "as much value as possible for shareholders" (Agle et al., 2008, p. 166). We might all agree that firms need profits to survive, but how they make profits is about stakeholder management and value creation; it's about purpose. An extract of Larry Fink's - Chairman and Chief Executive Officer at Blackrock Investments - letter to CEOs will be reported hereby, to provide evidence of what purpose and profit are perceived to be from a firm's standpoint:

\section{[...] Purpose is not the sole pursuit of profits but the animating force for achieving them. Profits are in no way inconsistent with purpose - in fact, profits and purpose are inextricably linked. Profits are essential if a company is to effectively serve all of its stakeholders over time - not only shareholders, but also employees, customers, and communities. [...]”" (Larry Fink's letter to CEOs 2019).}

This strengthens the idea that any sort of tradeoffs between the economic responsibilities of businesspeople and the social responsibilities of people implicates separating people from businesses. Even though we acknowledge that "organizations don't behave (people do)" (Rousseau, 1985, p. 7), a business without people does not come to life or expand. It is the actions and relationships of people that create value within and outside businesses (Bridoux \& Stoelhorst, 2016), and it is, therefore, businesses' and intellectuals' responsibility to acknowledge that business-as a unity of people in an interdependent relation with others-has multiple purposes and forms a key part of value creation processes that integrate multiple interests.

Even though some scholars support the thesis that there is a consistent and genuine difference between normative and descriptive matters as well as between business and ethics matters (Sandberg, 2008), rejection of the separation thesis is almost universally accepted through recognition that business and morality are intrinsically integrated; all decisions that businesses make have consequences and ethical implications, and they are the result of certain behaviors and moral conduct (Harris \& Freeman, 2008; Freeman, 2000; Wicks, 1996; Freeman, 1994). In Freeman's words: "Most people, most of the time, take, or want to take responsibility for the effects of their actions on others. And, if they did not, then what we call 'ethics' or 'morality' would be meaningless" (Freeman, 2000, p. 172). In their response to Sandberg's (2008) effort to convince Freeman of interpreting the separation thesis from other perspectives that could make it work under certain circumstances, Harris and Freeman (2008) reiterate that the failure of the separation thesis lies in the attempt to dichotomize and disentangle business facts and ethics facts, and separate economic value from moral value. Such separation is not only impossible, but also "purports moral neutrality while surreptitiously encapsulating certain ethical values and assertions" (Harris \& Freeman, 2008, p. 543).

Our idea is that, by acknowledging the separation fallacy, we can look at the economic life (i.e., not only the firm life) as a unified system and support Smith's view that efficient capitalism has a certain level of morality (Smith, 1776). Entrepreneurs, by definition, move from a vision and are preoccupied, at the same 
time, about economic returns on enterprising efforts and the "social contribution of the individual's effort" (Venkatamaran, 1997, p. 132). This assertion reinforces the meaning of integration as we intend it. We look at integration:

(a) between business and morality;

(b) among an enlarged spectrum of responsibilities for businesses, including economic, social, environmental and for all stakeholders;

(c) between the firm and their stakeholders; and mostly

(d) among all stakeholders, including the firm, and the surrounding industry and society.

Integration is the concept opposite to the separation thesis, not only semantically, but also descriptively and normatively; integration is key to describing our conceptualization of business' and stakeholders' relationships and responsibilities.

To reinforce the notion that trade-offs in business responsibilities might conduct to failures, we can discuss why, after 25 years of promoting the sustainability concept in the framework of the Triple Bottom Line (TBL) - as an integration of economic, social, and environmental impacts-John Elkington (2018) felt the need to recall such a concept despite the vast amount of literature and practical applications developed around it over the years. Apparently, many scholars and practitioners have continued to adopt the TBL as an accounting tool, with a trade-off mentality aimed at solving social and environmental issues once those issues in the economic sphere were achieved. In Elkington's mind, however, the TBL was designed to favor a new approach to capitalism - a new mindset that could integrate, not just balance, economic, social, and environmental aspects of companies' everyday actions and thinking.

One strong indicator that a new story of business based on integration is being written comes from the may attempts that the European Union has been doing since 2006 to integrate financial and non-financial reporting (Salvioni and Bosetti, 2014). In 2014, the European Union (EU) Directive 95, published on November 15 regulates the disclosure of nonfinancial information for companies with more than 500 employees by integrating such communication with that of the financial report. The aim is to increase the significance and comparability of information (Civera, 2018). According to Cantino and Cortese (2017): "Reporting tools are nodal: It is necessary to re-conceptualize them as comparable models of corporate communication" (p. 84). The compulsory inclusion of information of a mixed nature in the report (i.e., Nonfinancial or Integrated Report) is a sign of evolution in terms of accountability-from the logic of a simple checkbox-ticking tool toward an integrated system of communication that becomes understandable by multiple stakeholders and considers materiality (i.e., matters that influence the company's value creation over time), strategic focus and future orientation, connectivity of information, stakeholder relationships (IIRC $\left.{ }^{\mathrm{i}}, 2013\right)$ and value creation among all stakeholders (Jamali \& Carrol, 2017; Visser \& Kymal, 2015). 


\section{Adopting the Perspective of Continuous Engagement and Joint Value Creation}

In accordance with the idea that stakeholders' interests should be seen and perceived as joint, interdependent, and tied together, so should be the relationships that are formed between firms and stakeholders and among stakeholders' groups (Salvioni and Astori, 2013). Stakeholder engagement-intended as a process of positive stakeholder involvement (Greenwood, 2007)—creates an antecedent for building a stakeholder-oriented relational approach and is pivotal for establishing value creation processes based on jointness of interest and cooperation among all stakeholders (Strand \& Freeman, 2015). Greenwood (2007) posits that stakeholder engagement, "gives the impression of corporate responsibility" (p. 315), meaning that the higher the commitment firms show to their stakeholders, the more accountable and responsible they are toward stakeholders.

There are two types of engagement: firms' engagement with stakeholders and engagement of stakeholders with the firm (Civera et al., 2019). The former entails the establishment of an intrinsic stakeholder commitment model, where stakeholders' interests have an intrinsic value that is embedded in the company's core business and decisions and relationships are shaped accordingly (Berman et al., 1999). In the latter type, stakeholders feel highly positively committed to the firm and aligned with its values and purpose; it is the result of all the activities and practices that firms undertake to:

(a) create a favorable environment for stakeholders to express their needs and voices (Dawkins, 2014);

(b) obtain stakeholder consent (Van Buren, 2001) and trust (Greenwood \& Van Buren III, 2010);

(c) establish fairer relationships (Phillips, 1997);

(d) enable a collaborative mentality also in situations where stakeholders' demands create unexpected impacts and unintended consequences (Strand \& Freeman, 2015; Andriof et al., 2002); and

(e) empower more vulnerable and key stakeholders to favor the individual stakeholder's contribution to joint value creation (Civera et al., 2019; Bridoux \& Stoelhorst, 2016; Dawkins, 2014, 2015).

Andriof et al. (2002) postulate that stakeholder engagement is a process to enhance interaction, mutual dialogue, and respect, and to manage stakeholders in a dual-sided manner, avoiding the one-sided stakeholder management. The stakeholder relationships configuration modifies and turns into a network of collaboration, where there is no dominance and priority of perspective by one or more stakeholder groups, but all stakeholders can discuss and work on their agenda and objectives to facilitate solutions and solve conflicts, both at the industry and society levels. We hereby report the Sanofi's vision of stakeholder engagement (2017, Integrated Report):

"Listening to our stakeholders is essential to understand new societal expectations that are driving our ecosystem's evolution. Ongoing dialogue with stakeholders, such as patients, healthcare 
professionals, policymakers and many others, helps us develop a deeper understanding of their concerns and expectations. It helps guide our actions towards creating long-term value for all”. (Sanofi Integrated Report, 2017).

In this sense, stakeholder engagement posits an orientation to collaboration and partnering and allows stakeholders to become active partners in the value creation process. It can be, therefore, intended as a moral partnership of equals (Phillips, 1997), and even though "in reality, however, it is likely that the organisation and its stakeholders are not of equal status and that the terms of any cooperation are set by the most powerful party" (Greenwood, 2007; p. 318), we can assume that through continuous engagement and empowerment, stakeholders all become eligible to be partners. We can broaden the stakeholder relational thinking by putting the focus not necessarily on the firm as a central actor but as part of a joint value creation emergent process that works for the benefit of the industry and the society at large. In this way, the active process of stakeholder engagement-born out of the purposeful firmcreates mutual responsibilities that belong to all stakeholders (Andriof et al., 2002).

Joint value creation is the main outcome of both firms' engagement with stakeholders and engagement of stakeholders with the firm; besides being key within global and knowledge-based economies, joint value creation is about "mutually supportive contributions to value creation from multiple stakeholders whose tasks and outcomes are highly interdependent" (Bridoux \& Stoelhorst, 2016, p. 229). The importance of stakeholder engagement and interdependency for joint value creation is widely acknowledged by scholarship and it is thought that cooperative and interlinked relationships will eventually increase the effectiveness of social outcomes (Bridoux \& Stoelhorst, 2016; Freeman et al., 2010; Jones \& Wicks, 1999).

\section{Creative Imagination for Reconfiguring Multi-Stakeholder Relationships and Responsibilities}

Clearly, stakeholder theory has amplified the impact of business responsibilities (Jones \& Wicks, 1999), and embracing the perspective of a relational approach to stakeholder theory (Salvioni \& Astori, 2013) allows us to broaden the spectrum of responsibilities for both firms and stakeholders. In our view, new ideals for human beings, new challenging developments, and positive changes are arising all over the world, and a new story of business is being rewritten by firms and stakeholders that are using their moral imagination to become the catalysts of dramatic positive evolutions and transformations that integrate benefits for the society, the environment, and the industry(ies); these firms and stakeholders are responsible for their actions and for the others beyond their duties and requirements. To reconfigure firm and stakeholder relationships and responsibilities, moral imagination is crucial, as it brings us into a new territory; we must think beyond the mere transaction and envision the full range of possibilities - not merely those determined by present circumstance - to reframe and understand a phenomenon or a dilemma through new 
mental models (Werhane, 2015). We believe this is a necessary action when diverse groups of individuals come together to anticipate or solve social issues, for instance, or when we need to adopt novel assumptions for firm and stakeholder responsibilities by both broadening and integrating them across industries and societies in a way that is economically feasible and morally reasonable. Rethinking stakeholder relationships and responsibilities becomes even more necessary if we consider what Crane and Livesey (2003) define as "fluidity of situational contexts" (p. 45) in stakeholder thinking: Stakeholder groups are not static, and usually groups' roles and interests overlap and change depending on various circumstances and different contexts.

Following this widened logic, when we discuss CSR, we even tend to avoid this terminology, which seems to overlook the many responsibilities that firms have and the responsibilities that cannot transcend all stakeholders in interdependent relationships among themselves and with the firm. Therefore, CSR becomes Company Stakeholder Responsibility (Freeman \& Velamuri, 2006) or Integrated Company Responsibility (Civera, 2018) when we refer to the broader spectrum of integrated responsibilities that firms of any size have to their surroundings, their industry and all stakeholders-responsibilities that are essential to create higher value. Notwithstanding the key responsibility of firms in engaging with stakeholders for joint value creation, we argue that a broader stakeholder responsibility should be considered when talking about cooperation for value creation or multi-stakeholder initiatives conducted globally and in a cross-sector logic; such responsibility should be integrated in firms' and stakeholders' minds and actions for the benefit of the industry(ies) and the society(ies) that they live and operate in.

Indeed, there is an "emerging institutional infrastructure" of CSR that creates "new rules of the game" (Waddock, 2008, p. 105) for firms acting globally. These new rules include the progressive erosion of boundaries among various stakeholder groups, the change in the nature and levels of interactions, and the content of social relationships (Brondoni, 2014). The accent that the United Nations, through the SDGs (Sustainable Development Goals), put on the centrality of partnerships between governments, private sector, and civil society for a more effective sustainable development is one example of how institutions are changing their mindset towards embracing a multi-stakeholder orientation at all levels. We witness that a higher number of agents participate in the process of value creation with "new insights into the meaning of 'can affect' and 'is affected' in contemporary societies" (Lopez De Pedro \& Gilabert, 2012, p. 150). Direct and indirect effects that companies and stakeholders create are expanding and need to be moderated and tackled in different ways than in the past by configuring relationships that put higher responsibilities on and power in all actors involved, thus favoring a participatory model based on equality. If we look at the Lego's vision of their responsibilities, it is clear how, by achieving their purpose, they aim at positively affecting children's (the builders of tomorrow) approach to the world:

"At the LEGO Group, we're committed to playing our part in helping to build a sustainable future, and through the power of play 
inspire the children of today to become the builders of tomorrow. Play helps all of us imagine and create a better, brighter world for children to inherit. Working with our partners and local communities, we will continue to do our very best to nurture these builders of tomorrow, their environment and communities". (Lego, 2018 Responsibility Report).

In this sense, the emergence of multi-stakeholder actions allows for greater collaboration and partnership creation with goals and interests that surpass the traditional business focus (Andriof et al., 2002). It is here that firms have started engaging in a self-regulatory role to cover broader issues within society, environment, and markets that governments are not capable or able to cover. Clearly, the establishment of fair and balanced relationships is key to the groups' empowerment for higher participation (Civera et al., 2019; Freeman et al., 2018; Mena \& Palazzo, 2012).

If we think about multi-stakeholder initiatives (MSIs) as a growing phenomenon within global pressures of coping with sustainable and ethical imperatives, we look at the higher expression of integration between stakeholder theory and company stakeholder responsibility. MSIs not only provide some norms for corporate behaviors but also are the result of both firms' and stakeholders' behaviors as they are "the product of purposeful decisions and negotiations of pioneer members with diverse interests" (Zeyen et al., 2014, p. 342). This puts the responsibility on all stakeholders, including the firm, and implies a stronger cooperative strategic posture (Strand \& Freeman, 2015) among all groups involved. Since business never stands alone, it is intertwined with stakeholders and it is, as a matter of fact, an experience of cooperation. In effective MSIs, negotiations and decisions are not just about deciding, from a firm-centric perspective, in which initiatives stakeholders should be involved, but mostly about creating new networks of stakeholders where other actors become as central as the firm (Boiral \& Heras-Saizarbitoria, 2017) and make joint decisions in the interest of the industry and the society.

What if we change the conversation and the perspective of stakeholder relationships in a way based on interactive actions and higher integration of power and responsibilities among all actors involved in initiatives for value creation?

\section{The Multi-Stakeholder Value Map}

The multi-stakeholder value map that we illustrate is inspired by various academic contributions intended to rethink the firm-centric focus of stakeholder management and to reframe stakeholder assessment (Civera et al., 2019; McVea \& Freeman, 2005; Rowley \& Moldoveanu, 2003; Andriof et al., 2002; Waddock et al., 2002). Andriof et al. (2002) posit that stakeholder theory should no longer have a corporate-centric focus, according to which stakeholders, as well as their claims, interests and issues, are managed by the firm in a one-way perspective. Even though stakeholder management has implied mutuality since the very origins of stakeholder thinking 
(Freeman, 1984), looking at stakeholder relationships only from the firm's perspective might discourage the company and all other actors from considering the voices of stakeholders that are not deemed to be legitimate or powerful and, therefore, deny the possibility of valuable collaborations and stakeholder alliances in broader scopes (Derry et al., 2012). Furthermore, it may strengthen the power imbalances among stakeholders and underestimate the value of stakeholder empowerment for turning vulnerable actors into active partners in value creation (Civera et al., 2019; Dawkins, 2014, 2015).

That is why we claim a differentiated focus, which should be put on an emergent cooperative process where we see continuous interconnections of stakeholderscompany-stakeholders relationships_-which vary depending on the situational contexts (Crane and Livesey, 2003) - at the core of the debate. In this emergent process, those interdependent relationships based on stakeholders' continuous engagement can enable higher knowledge sharing, higher transparency, redefinition of power, joint value creation, and benefits for the industry and surrounding society.

Our idea is that stakeholders exist in a unity of multiple, variegated, and yet joint interests and conflicts, and that it is the power of relationships that creates the conditions for industry's and society's sustainable growth. Furthermore, it is reasonable to believe that and that relationships should replace transactions governed by the price mechanisms. Relationships are mixed in nature, and human beings frame them in a variety of ways, other than just following a market logic within the economic theory in a firm-centric view (Bridoux \& Stoelhorts, 2016).

We intend business to be a unity of people with responsibilities to share and the firm becomes a stakeholder, together with all other groups, of a joint value creation emergent process created within both the specific industry(ies) and the surrounding society. We want to focus on people with names and faces (McVea \& Freeman, 2005) and their possible interchangeable roles, interests, and claims, and it is individuals' actions and relationships that contribute to creation of value (Bridoux \& Stoelhorst, 2016) for not just the firm or their own personal needs, but for the industry and the society that permeate their living and working contexts. In this way, firms' and stakeholders' actions can be amplified.

Such an emergent process, which puts joint value creation at the center of the stakeholder map, is hereby named the "multi-stakeholder value map." It illustrates how we-all as stakeholders - are part of a process of value where stakeholder relationships are configured in a way that goes beyond their dependency on the company to include the moral standing of stakeholders (McVea \& Freeman, 2005) as well as their multiple identities, interests, and interdependencies in relation to a variety of surrounding environments and industries rather than just the company economics (Freeman et al., 2010).

Certainly, because stakeholder theory has been essential to break the rhetoric of ethics/finance separation, it has an inherently managerial nature (Freeman et al., 2010), and the firm, as a unity of people, is perceived by stakeholders as a central actor in value creation (Bridoux and Stoelhorst, 2016). Therefore, we do not intend at all to exclude the company and its management from the debate; instead, we claim an enlarged perspective of stakeholder theory that shifts the focus to the industry and 
the society that firms, customers, employees, partners, suppliers, governments, communities, and shareholders live and make decisions in. We also do not intend to stretch the notions of stakeholder engagement and stakeholder agency to an extreme, with the risk of falling into a system that Greenwood (2007) and stakeholder theorists and criticists alike define as anti-capitalism (i.e., too many stakeholders take part in the relationship in a way that might undermine the company's purpose).

Instead, we underline how, by adopting the perspective of joint value creation within an industry and the surrounding society, sometimes firms can indirectly benefit from multi-stakeholder actions aimed at improving some aspects and conditions within industries and societies. Such a perspective might keep companies from prioritizing in any way stakeholders' claims, while it can favor firms' alliances with collaborators, who were former competitors, in the interest of other stakeholders and the industry. In this way, "cooperative relationships based on trust and prior experience, or more broadly, social capital, do help reduce the adverse selection and moral hazard problems alluded to by economists" (Venkatamaran, 1997, p. 127).

Figure 1 shows the multi-stakeholder value map by integrating and interlinking all stakeholder groups, including the firm, in an emergent process of integrated relationships aimed at co-creating value (i.e., the center of the figure), which is the perspective from which we look at relationships and multi-stakeholder alliances. The inner dotted line represents the industry of that particular value creation process; the external line represents the surrounding society. As the figure illustrates, multistakeholder alliances can be created within the industry and the society by various groups of stakeholders, with integrated responsibilities and interdependencies, for achieving specific goals; they will eventually benefit the whole joint value creation process, including the firm's competitors, in that industry and the society at large. We propose that multi-stakeholder joint value creation processes allow for higher responsibility and participation of all actors involved in an environment of higher equality (in terms of power and responsibility) with the firm. This creates the antecedent for obtaining higher social outcomes and higher benefits for the industry and, therefore, positively affects all stakeholders in the process.

To provide one example to clarify such a design of a multi-stakeholder value map, we can look at what happens in the coffee industry. In previous studies on such a global and complex supply chain, scholars tried to revolutionize the traditional stakeholder theory perspective (i.e., the firm) and adopted that of farmers, who were considered vulnerable and powerless stakeholders in the coffee value chain (Civera et al., 2019; Candelo et al., 2018). This change of perspective allowed scholars to more effectively individuate the issues arising from farmers' relationships with other stakeholders, including the firm (i.e., global coffee roaster) and to better identify the areas in which farmers needed empowerment to become active partners in the joint value creation process. 


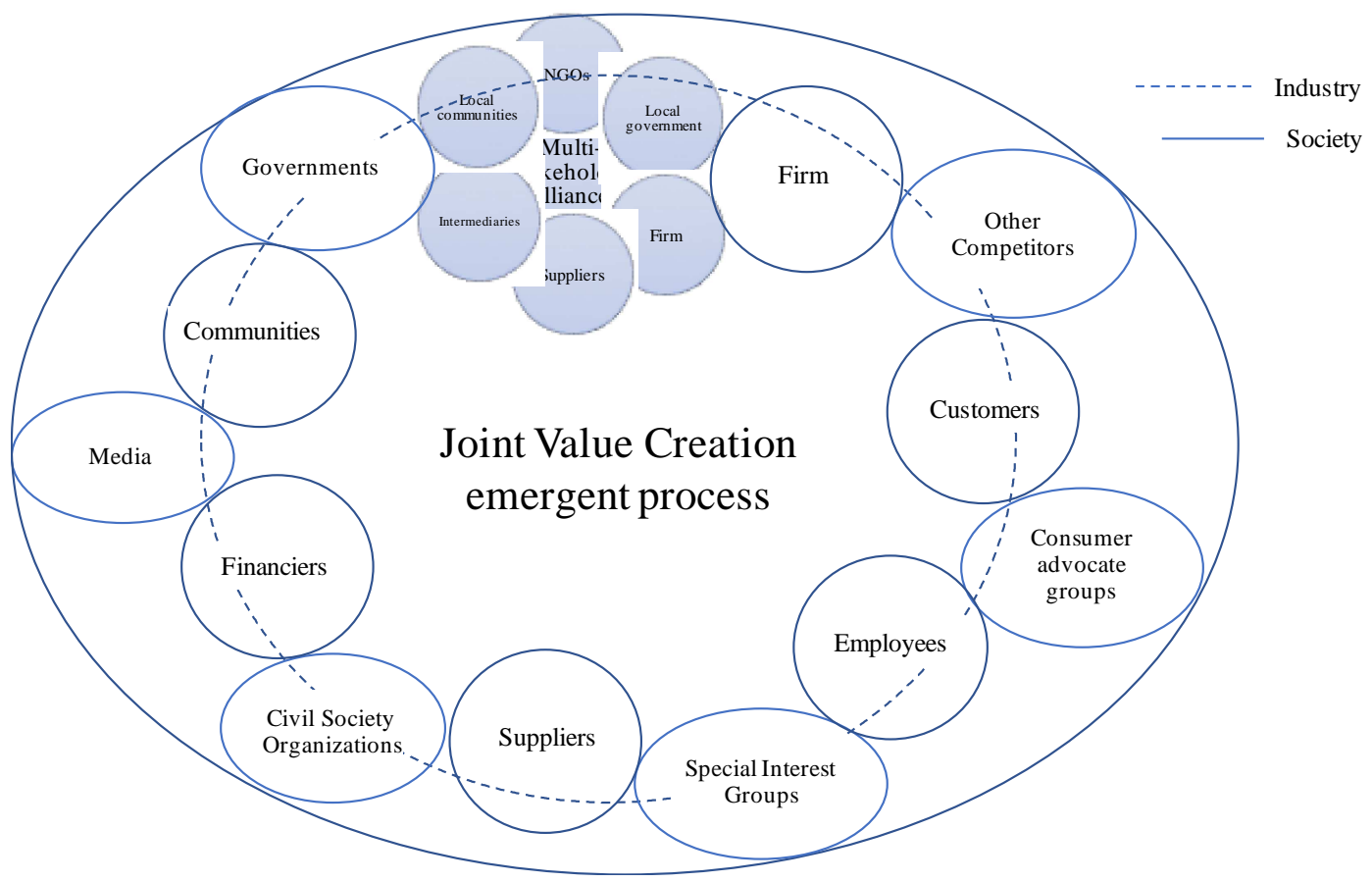

Source: Authors' elaboration

Authors found that one good example of a multi-stakeholder alliance was formed within the coffee industry with the aim of grouping together the global coffee roaster (Company A), farmers located in developing countries where coffee is being extracted, local nongovernmental organizations (NGOs), local governments, and intermediaries at a local level. This alliance worked to design and carry on sustainable projects of empowerment for vulnerable actors, to reduce the power asymmetries within the coffee value chain, to improve the overall quality of coffee, to protect the land, and to enhance the living conditions of farmers and their families, thereby boosting their capacity to actively participate in sustainable initiatives. Clearly, Company $\mathrm{A}$ is the stakeholder group making the financial investment to sustain empowerment actions and sustainability projects, and the power of relationships with other stakeholders, part of the alliance, allows for more effective and efficient decisions in this sense. The main benefit of such a multi-stakeholder alliance lays in the increased quality of produced coffee (e.g., higher varieties, taste and sustainability), which not only makes coffee more appealing for global roasters but also enhances the possibilities for farmers to sell it at a higher price to both intermediaries and any global coffee roasters interested in differentiated qualities of coffee. Through empowerment, farmers gain freedom and knowledge around their product and feel more engaged with their lands and with the coffee industry itself; the farmers are able to act like entrepreneurs and bargain their coffee beans with whichever roaster is willing to pay a fair price for their coffee, beyond Company A 
that originally made the investment. Now a question arises naturally: Why would a global coffee roaster invest in empowering projects and in activities to increase the quality of coffee that could eventually be also sold to competitors?

The answer needs a change of perspective in how we look at the way stakeholder relationships are framed. In this specific case, the authors found that the global coffee roaster adopted the broader perspective of the industry, instead of focusing only on its own economic sustainability, and thus acted in the interest of value creation for the society. Company A's management realized that the only way possible to maintain the coffee value chain for future decades was to invest in local people and make them aware of and engaged with the industry by improving their living conditions first, and then offering them training to develop new skills within the coffee extraction sector. They realized that farmers - especially the younger ones, who wish to abandon agricultural activities in favor of experiencing the city life needed to develop a higher commitment to their products; the management perceived that merely investing money in a corporate-centric logic for technical improvements on the land was not enough to sustain growth in the long term. It is farmers' entrepreneurial mentality and jointness of interest that needed to be reinforced in a logic of cooperation. Results from previous research studies show that now farmers are in the processes of being turned from vulnerable groups who were constantly in need of the company's financial support and were dependent on intermediaries into active and aware partners of value creation who were engaged with the coffee industry.

\section{Concluding Remarks and Emerging Issues}

In this paper, we have attempted to explore and discuss a differentiated view of stakeholder relationships and responsibilities to outline the potentialities that multistakeholder alliances might have if we adopt a joint value creation viewpoint (Civera et al., 2019; Bridoux \& Stoelhorst, 2016; Derry, 2012; McVea and Freeman, 2005; Andriof et al., 2002). We began by pointing out the three pillars that we consider fundamental to shedding light on a new story of business that allows us to rethink and reframe stakeholder relationships and responsibilities in a new perspective that puts joint value creation, in the interest of the industry(ies) and society(ies), at the core.

The outcome of this explicit conversation about the antecedents of a differentiated stakeholder perspective was a multi-stakeholder value map that looks at multistakeholder relationships in a way that can amplify the effects of companies' actions and partnerships. We argued that by increasing the engagement and the autonomy of stakeholder groups that were previously considered vulnerable and powerless in a firm-centric perspective, companies will eventually create mutual and shared responsibilities for the outcomes (Soundararajan et al., 2016; Andriof et al., 2002) and will integrate those responsibilities with such stakeholder groups in the industry. In this way, investments on projects that were previously the expression of a paternalistic and instrumental behavior can turn into a cooperative partnership for 
joint value creation where stakeholders' tasks and outcomes are highly interdependent (Bridoux \& Stoelhorst, 2016). This serves the interests of the industry, the society and all other stakeholder groups directly or indirectly involved in the multi-stakeholder alliance, thus resulting in higher social outcomes (Jones \& Wicks, 1999).

As this is an early study of differentiated interpretations of stakeholder relationships and responsibilities, we aim to further refine such theoretical thinking by testing whether it functions in multiple industries. Furthermore, studies that will investigate mechanisms through which firms can adopt a different perspective, develop a higher cooperative strategic posture, and integrate responsibilities with other stakeholder groups in the interest of the industry and the society are welcome.

Despite further adjustments of our thinking are recommended, we do hope to have substantiated a consistent argument within the new story of business: the need to replace a pure perspective of stakeholder dependency and economic theory's focus on transactions with more equal, fair, and interdependent stakeholder relationships and responsibilities configuration, in the interest of the industry(ies) and the society(ies), through a joint value creation emergent process.

\section{Bibliography}

Agle, B. R., Donaldson, T., Freeman, R. E., Jensen, M. C., Mitchell, R. K., \& Wood, D. J. (2008). Dialogue: Toward Superior Stakeholder Theory, Business Ethics Quarterly, 18(2), 153-190. http://dx.doi.org/10.5840/beq200818214

Andriof, J., Waddock, S., Husted, B., \& Rahman, S. S. (2002). Unfolding Stakeholder Thinking: Theory, Responsibility and Engagement, E-book: 2017, Routledge, New York.

http://dx.doi.org/10.4324/9781351281881

Berman, S. L., Wicks, A. C., Kotha, S., \& Jones, T. M. (1999). Does Stakeholder Orientation Matter? The Relationship between Stakeholder Management Models and Firm Financial Performance, The Academy of Management Journal, 42(5), 488-506.

http://dx.doi.org/doi:10.2307/256972

Boiral, O., \& Heras-Saizarbitoria, I. (2017). Managing Biodiversity through Stakeholder Involvement: Why, Who, and for What Initiatives?, Journal of Business Ethics, 140(3), 403-421.

http://dx.doi.org/10.1007/s10551-015-2668-3

Bridoux, F., \& Stoelhorst, J. W. (2016). Stakeholder Relationships and Social Welfare: A Behavioral Theory of Contributions to Joint Value Creation, The Academy of Management Review, 41(2), 229251.

http://dx.doi.org/10.5465/amr.2013.0475

Brondoni, S. M. (2014). Global Capitalism and Sustainable Growth. From Global Products to Network Globalisation, Symphonya. Emerging Issues in Management (symphonya.unimib.it), (1), 10-31. http://dx.doi.org/10.4468/2014.1.02brondoni

Brondoni, S. M. (2003). Network Culture, Performance \& Corporate Responsibility. Symphonya. Emerging Issues in Management (symphonya.unimib.it), (1), 8-24.

http://dx.doi.org/10.4468/2003.1.02brondoni 
Candelo, E., Casalegno, C., Civera, C., \& Mosca, F. (2018). Turning Farmers into Business Partners through Value Co-Creation Projects. Insights from the Coffee Supply Chain, Sustainability, 10(4), 1018.

http://dx.doi.org/10.3390/su10041018

Cantino, V., \& Cortese, D. (2017). Integrated Report System in Italian Law, Symphonya. Emerging Issues in Management (symphonya.unimib.it), (1), 83-94. http://dx.doi.org/10.4468/2017.1.07cantino.cortese

Civera, C., De Colle, S., \& Casalegno, C. (2019). Stakeholder engagement through empowerment: The case of coffee farmers, Business Ethics: A European Review, 28(2), 156-174. http://dx.doi.org/10.1111/beer.12208

Civera, C. (2018). Integrated Company Responsibility in the Food and Beverage Industry. Giappichelli, Turin.

Crane, A. and Livesey, S. (2003). Are You Talking to Me? StakeholderCommunication and the Risks and Rewards of Dialogue, J. Andriof, S. Waddock, S. Rahman and B. Husted (eds.), Unfolding Stakeholder Thinking 2: Relationships, Communication, Reporting And Performance, Greenleaf, Sheffield.

Dawkins, C. (2015). Agonistic Pluralism and Stakeholder Engagement, Business Ethics Quarterly, 25(1), 1-28. http://dx.doi.org/10.1017/beq.2015.2

Dawkins, C. E. (2014). The Principle of Good Faith: Toward Substantive Stakeholder Engagement. Journal of Business Ethics, 121(2), 283-295.

http://dx.doi.org/10.1007/s10551-013-1697-z

Derry, R. (2012). Reclaiming Marginalized Stakeholders, Journal of Business Ethics, 111(2), 253264.

http://dx.doi.org/10.1007/s10551-012-1205-x

Elkington, J. (2018) 25 Years Ago I Coined the Phrase “Triple Bottom Line.” Here's Why It's Time to Rethink It, Harvard Business Review, June 25.

EU Directive (2014). Directive 2014/95/EU of the European Parliament and the Council of 22 October 2014 amending Directive 2013/34/EU as Regards Disclosure of Non-Financial and Diversity Information by Certain Large Undertakings and Group,. EU L 330: 1-9

Fassin, Y., De Colle, S., \& Freeman, R. E. (2017). Intra-Stakeholder Alliances in Plant-Closing Decisions: A Stakeholder Theory Approach, Business Ethics: A European Review, 26(2), 97-111. http://dx.doi.org/10.1111/beer.12136

Freeman, E. R., Civera, C., Cortese, D., \& Fiandrino, S. (2018). Strategising Stakeholder Empowerment for Effective Co-Management within Fishery-Based Commons, British Food Journal, 120(11), 2631-2644.

http://dx.doi.org/10.1108/BFJ-01-2018-0041

Freeman, R. E., \& Dmytriyev, S. (2017). Corporate Social Responsibility and Stakeholder Theory: Learning from Each Other, Symphonya. Emerging Issues in Management (symphonya.unimib.it), (1), 7-15. http://dx.doi.org/10.4468/2017.1.02freeman.dmytriyev

Freeman R. E., Wicks A., Harrison J., Parmar B., S. de Colle (2010). Stakeholder Theory: The State of The Art, Cambridge University Press, Cambridge.

http://dx.doi.org/10.1080/19416520.2010.495581

Freeman, R. E., \& Velamuri, S. R. (2006). A New Approach to CSR: Company Stakeholder Responsibility, Corporate Social Responsibility (pp. 9-23). Palgrave Macmillan, London.

Freeman, R. E. (2000). Business Ethics at the Millennium, Business Ethics Quarterly, 10(1), 169-180. 
http://dx.doi.org/10.2307/3857703

Freeman, R. E. (1994). The Politics of Stakeholder Theory: Some Future Directions, Business Ethics Quarterly, October, 4, 409-421.

http://dx.doi.org/10.2307/3857340

Freeman R.E. (1984), Strategic Management: A Stakeholder Approach, Pitman, Boston.

Friedman, M. (1970). The Social Responsibility of Firms is to Increase its Profits, New York Times Magazine.

http://dx.doi.org/10.1007/978-3-540-70818-6_14

Friedman, M. (1962). Capitalism and Freedom, University of Chicago Press and Phoenix Books, Chicago.

Greenwood, M. (2007). Stakeholder Engagement: Beyond the Myth of Corporate Responsibility, Journal of Business Ethics, 74(4), 315-327.

http://dx.doi.org/10.1007/s10551-007-9509-y

Greenwood, M., \& Van Buren III, H. J. (2010). Trust and Stakeholder Theory: Trustworthiness in the Organisation-Stakeholder Relationship, Journal of Business Ethics, 95(3), 425-438.

http://dx.doi.org/10.1007/s10551-010-0414-4

Harris, J. D., \& Freeman, R. E. (2008). The Impossibility of the Separation Thesis: A Response to Joakim Sandberg, Business Ethics Quarterly, 18(4), 541-548.

http://dx.doi.org/10.5840/beq200818437

Harrison, J. S., Bosse, D. A., \& Phillips, R. A. (2010). Managing for Stakeholders, Stakeholder Utility Functions, and Competitive Advantage, Strategic Management Journal, 31(1), 58-74.

http://dx.doi.org/10.1002/smj.801

Harrison J.S, Freeman R.E. (1999), Stakeholders, Social Responsibility, and Performance: Empirical Evidence and Theoretical Perspectives, The Academy of Management Journal, Oct., 479-485.

http://dx.doi.org//10.2307/256971

International Integrated Reporting Council (IIRC) (2013) The International <IR> Framework. http://integratedreporting.org/wp-content/uploads/2013/12/13-12-08-THEINTERNATIONALIRFRAMEWORK-2-1.pdf

Jamali, D., \& Carroll, A. (2017). Capturing Advances in CSR: Developed Versus Developing Country Perspectives, Business Ethics: A European Review, 26(4), 321-325.

http://dx.doi.org/10.1111/beer.12157

Jones, T. M., \& Felps, W. (2013). Stakeholder Happiness Enhancement: A Neo-Utilitarian Objective for the Modern Corporation, Business Ethics Quarterly, 23(3), 349-379.

http://dx.doi.org/10.5840/beq201323325

Jones, T. M., \& Wicks, A. C. (1999). Convergent Stakeholder Theory. Academy of Management Review, 24(2), 206-221.

http://dx.doi.org/10.5465/amr.1999.1893929

Lopez-De-Pedro, J. M., \& Rimbau-Gilabert, E. (2012). Stakeholder Approach: What Effects Should We Take into Account in Contemporary Societies?, Journal of Business Ethics, 107(2), 147-158. http://dx.doi.org/10.1007/s10551-011-1029-0

McVea, J. F., \& Freeman, R. E. (2005). A Names-And-Faces Approach to Stakeholder Management: How Focusing on Stakeholders as Individuals Can Bring Ethics and Entrepreneurial Strategy Together, Journal of Management Inquiry, 14(1), 57-69.

http://dx.doi.org/10.1177/1056492604270799

Mena, S., \& Palazzo, G. (2012). Input and Output Legitimacy of Multi-Stakeholder Initiatives, Business Ethics Quarterly, 22(3), 527-556. 
http://dx.doi.org/10.5840/beq201222333

Mitchell, R. K., Agle, B. R., \& Wood, D. J. (1997). Toward a Theory of Stakeholder Identification and Salience: Defining the Principle of Who and What Really Counts, Academy of Management Review, 22(4), 853-886.

http://dx.doi.org/10.2307/259247

Mosca, F., \& Civera, C. (2017). The Evolution of CSR: An Integrated Approach, Symphonya. Emerging Issues in Management (symphonya.unimib.it), (1), 16-35. http://dx.doi.org/10.4468/2017.1.03mosca.civera

Phillips, R. A. 1997. Stakeholder Theory and a Principle of Fairness, Business Ethics Quarterly, 7: 51-66.

Rousseau, D. M. (1985). Issues of Level in Organizational Research: Multi-Level and Cross-Level Perspectives, Research in Organizational Behavior, 7(1), 1-37.

Rowley, T. I., \& Moldoveanu, M. (2003). When will Stakeholder Groups Act? An Interest-And Identity-Based Model of Stakeholder Group Mobilization, Academy of Management Review, 28(2), 204-219.

http://dx.doi.org/10.2307/30040709

Salvioni, D., \& Bosetti, L. (2014). Sustainable Development and Corporate Communication in Global Market. Symphonya Emerging Issues in Management (symphonya.unimib.it), 1, 32-51.

http://dx.doi.org/10.4468/2014.1.03salvioni.bosetti

Salvioni, D., \& Astori, R. (2013). Sustainable Development and Global Responsibility in Corporate Governance, Symphonya Emerging Issues in Management(symphonya.unimib.it), 1, 38-52.

http://dx.doi.org/10.4468/2013.1.03salvioni.astori

Sandberg, J. (2008). Understanding the Separation Thesis, Business Ethics Quarterly, 18(2), 213-232. http://dx.doi.org/10.5840/beq200818216

Soundararajan, V., Brown, J. A., \& Wicks, A. C. (2016, January). An Instrumental Perspective of Value Creation through Multi-Stakeholder Initiatives, Academy of Management Proceedings (Vol. 2016, No. 1, p. 10598, Academy of Management. http://dx.doi.org//doi:10.5465/AMBPP.2016.10598abstract

Smith, A. (1776). TheWwealth of Nations, The Modern Library.

Strand, R., \& Freeman, R. E. (2015). Scandinavian Cooperative Advantage: The Theory and Practice of Stakeholder Engagement in Scandinavia, Journal of Business Ethics, 127(1), 65-85. http://dx.doi.org/10.1007/s10551-013-1792-1

Tashman, P., \& Raelin, J. (2013). Who and What Really Matters to the Firm: Moving Stakeholder Salience Beyond Managerial Perceptions, Business Ethics Quarterly, 23(4), 591-616. http://dx.doi.org/10.5840/beq201323441

Van Buren, H. (2001). If Fairness Is the Problem, Is Consent the Solution? Integrating ISCT and Stakeholder Theory, Business Ethics Quarterly, 11(3), 481-499.

http://dx.doi.org/10.2307/3857850

Venkataraman, S. (1997). The Distinctive Domain of Entrepreneurship Research, in Shane, S. (ed.), Foundations of Entrepreneurship, Edward Elgar Press, New York.

Visser, W., \& Kymal, C. (2015). Integrated Value Creation (IVC): Beyond Corporate Social Responsibility (CSR) and Creating Shared Value (CSV), Journal of International Business Ethics, 8(1), 29.

Waddock, S. (2008). Building a New Institutional Infrastructure for Corporate Responsibility. Academy of Management Perspectives, 22(3), 87-108.

http://dx.doi.org/10.5465/amp.2008.34587997 
(C) SYMPHONYA Emerging Issues in Management, n. 1, 2019

symphonya.unicusano.it

Waddock, S. A., Bodwell, C., \& Graves, S. B. (2002). Responsibility: The New Business Imperative. The Academy of Management Executive, 16(2), 132-148.

http://dx.doi.org/10.5465/AME.2002.7173581

Werhane, P. H. (2015). Moral Imagination, Wiley Encyclopedia of Management, 1-2 John Wiley.

Wicks, A. C. (1996). Overcoming the Separation Thesis: The Need for a Reconsideration of Business and Society Research, Business \& Society, 35(1), 89-118.

http://dx.doi.org/10.1177/000765039603500108

www.blackrock.com

www.lego.com

www.sanofi.com

Zeyen, A., Beckmann, M., \& Wolters, S. (2016). Actor and Institutional Dynamics in the Development of Multi-Stakeholder Initiatives, Journal of Business Ethics, 135(2), 341-360.

http://dx.doi.org/10.1007/s10551-014-2468-1

\section{Notes}

${ }^{\text {i } I I R C: ~ T h e ~ I n t e r n a t i o n a l ~ I n t e g r a t e d ~ R e p o r t i n g ~ C o u n c i l ~(I I R C) ~ i s ~ a ~ g l o b a l ~ c o a l i t i o n ~ o f ~ r e g u l a t o r s, ~}$ investors, companies, standard setters, members of the accounting profession, and NGOs. The coalition believes that communication about value creation should be the next step in the evolution of corporate reporting. See http://integratedreporting.org. 